\title{
A Precambrian microcontinent in the Indian Ocean
}

\author{
Trond H. Torsvik ${ }^{1,2,3,4,5 \star \dagger}$, Hans Amundsen ${ }^{6}$, Ebbe H. Hartz ${ }^{1,7}$, Fernando Corfu ${ }^{4}$, Nick Kusznir ${ }^{8}$, \\ Carmen Gaina ${ }^{1,2,4}$, Pavel V. Doubrovine ${ }^{1,2 \dagger}$, Bernhard Steinberger ${ }^{1,2,9}$, Lewis D. Ashwal ${ }^{5}$ \\ and Bjørn Jamtveit ${ }^{1}$
}

The Laccadive-Chagos Ridge and Southern Mascarene Plateau in the north-central and western Indian Ocean, respectively, are thought to be volcanic chains formed above the Réunion mantle plume ${ }^{1}$ over the past 65.5 million years ${ }^{2,3}$. Here we use $\mathrm{U}-\mathrm{Pb}$ dating to analyse the ages of zircon xenocrysts found within young lavas on the island of Mauritius, part of the Southern Mascarene Plateau. We find that the zircons are either Palaeoproterozoic (more than 1,971 million years old) or Neoproterozoic (between 660 and 840 million years old). We propose that the zircons were assimilated from ancient fragments of continental lithosphere beneath Mauritius, and were brought to the surface by plume-related lavas. We use gravity data inversion to map crustal thickness and find that Mauritius forms part of a contiguous block of anomalously thick crust that extends in an arc northwards to the Seychelles. Using plate tectonic reconstructions, we show that Mauritius and the adjacent Mascarene Plateau may overlie a Precambrian microcontinent that we call Mauritia. On the basis of reinterpretation of marine geophysical data ${ }^{4}$, we propose that Mauritia was separated from Madagascar and fragmented into a ribbon-like configuration by a series of mid-ocean ridge jumps during the opening of the Mascarene ocean basin between 83.5 and 61 million years ago. We suggest that the plume-related magmatic deposits have since covered Mauritia and potentially other continental fragments.

Intra-plate magmatic activity is commonly attributed to melting associated with an upwelling mantle plume. Mantle plumes may also trigger continental break-up and continental fragments may hence be placed along an oceanic hotspot track. A dozen hotspot volcanoes_including Réunion (Fig. 1) - and most reconstructed large igneous provinces since Pangaea assembly ( $2320 \mathrm{Myr} \mathrm{вр)}$ are thought to be sourced by deep plumes from the edges of the two large low shear-wave velocity provinces at the core-mantle boundary ${ }^{5,6}$. Recent volcanics erupted at the island of Réunion show geochemical signatures indicative of homogeneous mantle domains $^{7}$, whereas lavas from Mauritius show much more heterogeneous isotopic compositions. Mauritian basalts ${ }^{8,9}$ are divided into Older (8.9-5.5 Myr в ), Intermediate (3.5-1.9 Myr вр) and Younger (1-0.03 Myr $\mathrm{BP})$ series that are geochemically and isotopically distinct, and have been proposed to form from a variety of source components, including variably enriched and depleted peridotites, as well as pods of more enriched material, possibly pyroxenites and/or eclogites ${ }^{9-11}$.

Here we report Precambrian zircons recovered from basaltic beach sands on Mauritius, $900 \mathrm{~km}$ from the nearest continental crust (Madagascar). Some twenty zircon grains were recovered from two basaltic sand samples from the northwest (Sample E04-1) and southeast (Sample MBS1) coast of Mauritius. The use of sand samples avoids potential contamination from rock-crushing apparatus. The zircons are generally subhedral to anhedral, show diversity in shape and presence of inclusions, and range in size from 50 to $300 \mu \mathrm{m}$. The zircons were analysed for $\mathrm{U}$ and $\mathrm{Pb}$ isotopes by thermal ionization mass spectrometry (Fig. 2 and Supplementary Table S1). Sample E04-1 from the Intermediate Series yielded fifteen zircon grains; six were selected for analysis. Sample MBS1 from the Older Series had fewer zircons and two were used for age determination. Most results are discordant (Fig. 2), but all data indicate a Proterozoic age of the grains. The oldest grain has a minimum age of $1971 \mathrm{Myr}$. Three grains yield ages between 1,400 and 900 Myr. Four grains are Neoproterozoic, two grains showing discordant ${ }^{207} \mathrm{~Pb} /{ }^{206} \mathrm{~Pb}$ ages of $\sim 840 \mathrm{Myr}$, one grain yielding a concordant age of $790 \mathrm{Myr}$, and another grain showing a reversely discordant age of $\sim 690-660 \mathrm{Myr}$ (Supplementary Table S1). Their presence in exclusively basaltic detritus suggests that they were brought up by mafic magmas that assimilated underlying sialic crust, probably at relatively shallow levels. There is no clear-cut geochemical or isotopic signature of continental crust in the Mauritian basalts, although some of their variability in $\varepsilon_{\mathrm{Nd}}$ values (3.9-6.1; refs 9,10) could indicate variable crustal contamination. We suggest that a crustal signature need not be detectable in basaltic lavas that carry xenocrystic zircons. Although small amounts of zircon have been found as crystallization products in young oceanic mafic volcanics and intrusives ${ }^{12,13}$, older xenocrystic zircons have been reliably documented only from oceanic gabbros drilled at the Mid-Atlantic Ridge ${ }^{14}$. The young Mid-Atlantic Ridge gabbros that contain old xenocrystic zircons have lower $\mathrm{Zr}$ concentrations ${ }^{14}$ (mean $\sim 20$ ppm) than Mauritian basalts ${ }^{9}$ (mean $\sim 145 \mathrm{ppm}$ ), and also lack geochemical indicators of continental crust assimilation.

To identify regions in the northwest Indian Ocean that may be underlain by continental crust, we determined crustal thicknesses by gravity anomaly inversion incorporating a lithosphere thermal gravity anomaly correction ${ }^{15}$. The gravity inversion predicts contiguous crust of thickness $>25-30 \mathrm{~km}$ beneath the Seychelles and northern Mascarenes, which extends southwards towards Mauritius (Fig. 1). Sensitivity tests (Supplementary Fig. S1) show that predicted crustal thicknesses from gravity inversion under the Seychelles, Mascarenes, Mauritius, Laccadives, Maldives and Chagos are not significantly dependent on break-up and ocean age isochrons used to determine the lithosphere thermal gravity anomaly correction. Crustal thickness determined from gravity

\footnotetext{
${ }^{1}$ Physics of Geological Processes, University of Oslo, 0316 Oslo, Norway, ${ }^{2}$ Center of Advanced Study, Norwegian Academy of Science and Letters, 0271 Oslo, Norway, ${ }^{3}$ Geodynamics, NGU, N-7491 Trondheim, Norway, ${ }^{4}$ Geosciences, University of Oslo, 0316 Oslo, Norway, ${ }^{5}$ School of Geosciences, University of Witwatersrand, WITS 2050, South Africa, ${ }^{6}$ EPX, Jacob Aalls Gate 44b, N-0364 Oslo, Norway, ${ }^{7}$ Det norske oljeselskap, Postboks 2070 Vika, 0125 Oslo, Norway, ${ }^{8}$ Department of Earth and Ocean Sciences, University of Liverpool, Liverpool L69 3BX, UK, ${ }^{9}$ Helmholtz Centre Potsdam, GFZ German Research Centre for Geosciences, Heinrich-Mann-Allee 18/19, 14473 Potsdam, Germany. 'Present address: Centre for Earth Evolution and Dynamics, University of Oslo, 0316 Oslo, Norway. *e-mail: t.h.torsvik@geo.uio.no.
} 


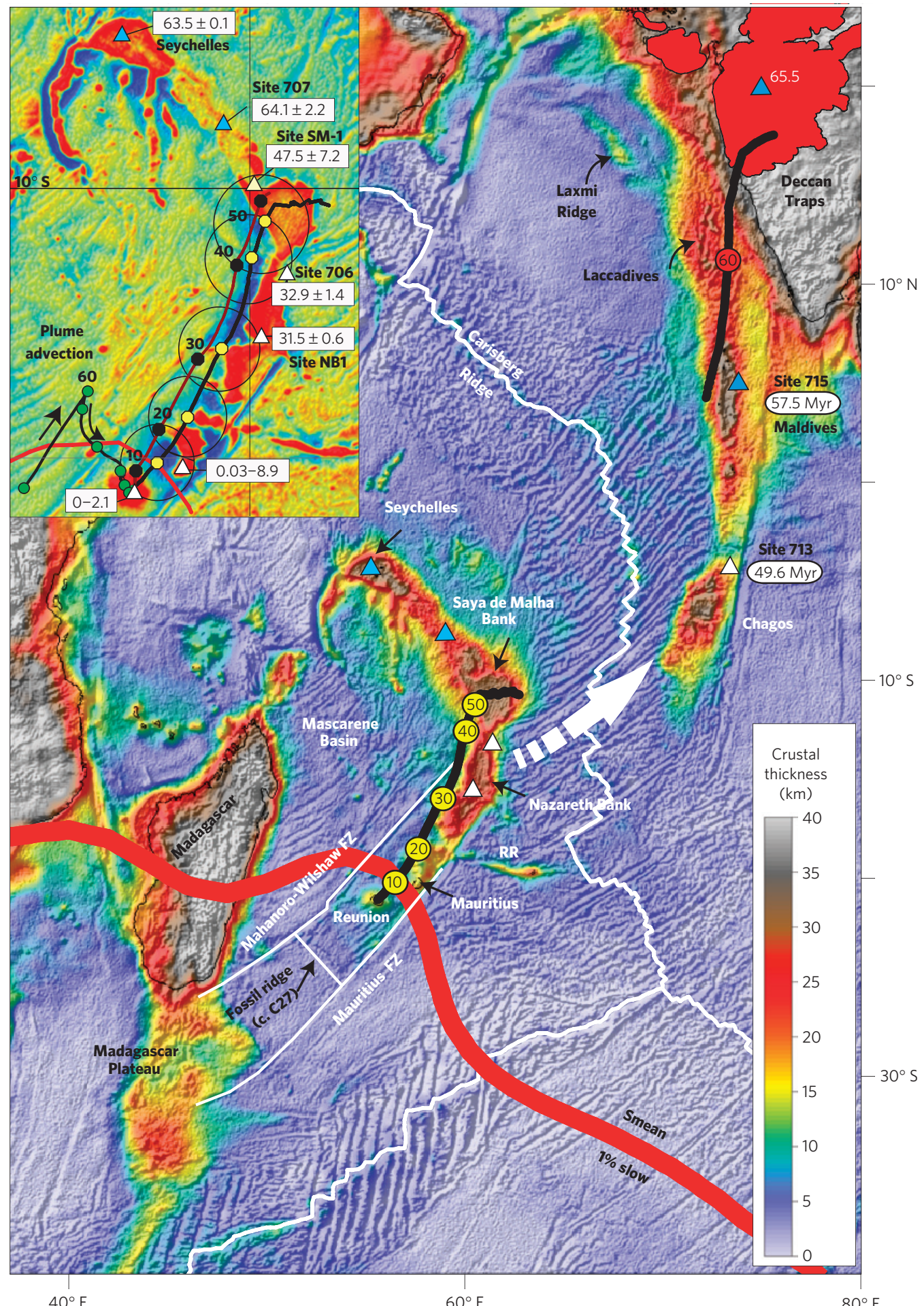

Figure 1 | Crustal thickness map based on gravity inversion and the Réunion hotspot chain. Circled numbers denote times (Myr) when the Réunion plume ${ }^{26}$ was beneath or near the Indian (red circle) or African plates. Triangles denote dated sites (see also inset map for ages). The red line is the $1 \%$ slow contour in the SMEAN model ${ }^{31}$, approximating the plume generation zone ${ }^{5,6}$ at the core-mantle boundary. RR, Rodriguez Ridge. The inset map shows free-air gravity, predicted Réunion track as in the large map but with 95\% confidence ellipses and the calculated surface hotspot motion ${ }^{26}$ (black line with green circles). The second track (maroon line with black circles) is calculated by excluding the Réunion track when calculating the global mantle reference frame (Supplementary Fig. S7).

inversion for the Seychelles is consistent with wide-angle seismic studies ${ }^{16}$ where crustal thicknesses of $32 \mathrm{~km}$ and velocity structure are interpreted as continental. On the conjugate Indian margin, the Laccadives, Maldives and Chagos also seem to be underlain by contiguous crust of thickness $>25-30 \mathrm{~km}$. Seismic Moho depths
( $\sim 24 \mathrm{~km}$ ) beneath the Laccadives ${ }^{17}$ and crustal thicknesses from Chagos (up to $27 \mathrm{~km}$ ) obtained from gravity modelling ${ }^{18}$ are similar to our thickness estimates. These regions of thick crust identified by gravity inversion are surrounded by oceanic crust of thickness typically $<5-10 \mathrm{~km}$ within the Mascarene Basin, between the 


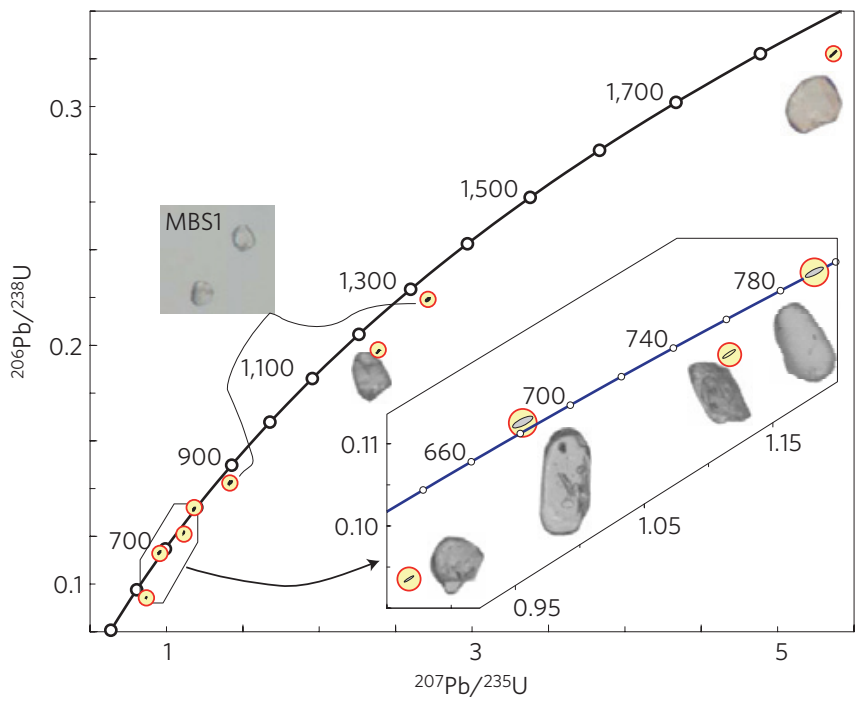

Figure 2 | U-Pb concordia diagram. Data are shown with $2 \sigma$ error ellipses (Supplementary Table S1) surrounded by yellow circles. Corresponding zircon grains are shown in microscope view before analysis. The two largest grains, which give concordant to nearly concordant results at $\sim 790$ and 680 Myr BP, are $\sim 300 \mu \mathrm{m}$ long. The two grains from MBS1 were the smallest ( $\sim 50 \mu \mathrm{m}$ each).

Seychelles-Mascarenes and Laccadives-Maldives-Chagos Ridge, and to the east of the Laccadives-Maldives-Chagos Ridge. Crustal thickness patterns, oceanic fracture zones revealed by the free-air gravity anomaly and plate reconstructions strongly suggest that Chagos was originally joined to the Mascarene Plateau (Fig. 1 and Supplementary Figs S1 and S2). It should be noted that crustal thickness mapping using gravity inversion cannot distinguish thinned continental crust from anomalously thick oceanic crust.

Our new U-Pb data demonstrate that the proposed Palaeoproterozoic continental crust $(\geq 1971 \mathrm{Myr})$ beneath Mauritius underwent reworking/magmatism during the Neoproterozoic era (840-660 Myr вр). This continental signature is recognized in surface exposures from both Madagascar and India, and Neoproterozoic arc-related magmatism $(800-700 \mathrm{Myr} \mathrm{BP})$ is well known in the Seychelles and northwest India ${ }^{19-21}$. We place the post-750 Myr в position of Mauritius between southern India and Madagascar (Fig. 3 and Supplementary Fig. S3) and further propose that thinned continental crust beneath the Laxmi Ridge ${ }^{16}$ is of Neoproterozoic age, and was originally juxtaposed to the Seychelles and the Malani province in India (Supplementary Fig. S3). We name the proposed sub-volcanic crust of Mauritius, and potentially other continental fragments from the Southern Mascarene Plateau (for example, parts of Saya de Malha, Nazareth and Cargados-Carajos Banks) and from the conjugate Indian margin (Laccadives and Chagos) as Mauritia.

Mauritian continental lithosphere was thinned, fragmented and concealed during Cretaceous-Cenozoic times. A Late Cretaceous large igneous province event ( $91-84 \mathrm{Myr} \mathrm{BP})$, which we attribute to the Marion plume, first blanketed most of Madagascar ${ }^{22}$ (horizontal stripes in Fig. 3a), parts of southwest India ${ }^{23}$ and probably also Mauritia with flood basalts. The plume centre was probably located near the southern tip of Madagascar (Fig. 3a). The Mascarene Basin opened shortly thereafter, separating India from Madagascar and the African Plate. In our model, Mauritius and other parts of Mauritia were attached to Madagascar, but were gradually transferred to the Indian Plate as a northeast-southwest ribbon-like structure that parallels the Mahanoro-Wilshaw and Mauritius fracture zones (Fig. 1) through a system of southwestpropagating ridge jumps, adding more crust to the Indian Plate (Supplementary Figs S4 and S5). We model three major ridge jumps (80, about 73.6 and 70 Myr вP; Fig. 3b), and by 70 Myr в all Mauritian fragments were transferred to the Indian Plate. Following the peak of Deccan magmatism (65.5 Myr вP), seafloor spreading was initiated between the Laxmi Ridge and the Seychelles (62-63 Myr ; refs 24,25) with seafloor spreading probably still ongoing in the Mascarene Basin. Shortly after 61 Myr вP (chron C27), the Réunion plume was located beneath the southwest margin of India, which probably triggered a major northeast ridge jump that led to the termination of seafloor spreading in the Mascarene Basin. By 56 Myr вP, the Mauritian fragments (except Laccadives) and the Seychelles became part of the African Plate (Supplementary Fig. S5). Thereafter, the Réunion plume was located beneath the slowly moving African Plate $\left(\sim 2 \mathrm{~cm} \mathrm{yr}^{-1}\right)$. A southwest ridge jump around $41 \mathrm{Myr}$ в resulted in Chagos breaking away from the Mascarene Plateau and becoming part of the Indian Plate (Fig. 3c and Supplementary Fig. S5). Continuing volcanic activity later modified the Southern Mascarene Plateau.

Coincidence of a plume track and continental fragments may result if the plume assists in breaking off these fragments. Palaeomagnetic data corrected for true polar wander (Supplementary Fig. S6a) from Deccan volcanics and Deep Sea Drilling Project Leg 115 Sites 715 and 707 (Fig. 1) are compatible with a moving hotspot model ${ }^{26}$, and this, together with the general volcanic ridge geometry and age progression, strongly supports a deeply sourced plume beneath Réunion. Our plate model ${ }^{26}$, based on five hotspot tracks (including Réunion), does, however, predict a hotspot track west of the main chain of volcanic islands and submarine plateaus. However, even if the Réunion track is not used to construct a global model, the predicted track is remarkably similar (Supplementary Fig. S7 and Fig. 1 inset map). The trend of the Réunion chain is therefore close to what is expected from a global plate motion model, but the predicted track is $\sim 100 \mathrm{~km}$ westward along the Southern Mascarene Plateau. This region is located within a $\sim 350-\mathrm{km}$-wide zone limited by two major fracture zones ${ }^{27}$ that separate lithosphere of different ages (Supplementary Fig. S7) and thickness. Mauritius and the Nazareth Bank are located at or near the Mauritius fault zone, probably as a result of plume material travelling up-slope and eastwards towards younger and thinner oceanic lithosphere ${ }^{28}$.

Basalt compositions along the Réunion hotspot chain vary with time towards less mid-ocean-ridge basalt (MORB)-like (less depleted) isotopic signatures ${ }^{29}$. This trend is best understood by examining isotopic compositions versus distance from the spreading ridge at the time of eruption (Supplementary Fig. S6b,c). During eruption of the Deccan Traps, the Réunion plume was located beneath India and more than $500 \mathrm{~km}$ from an active spreading ridge (Supplementary Fig. S6b), but prominent ridge jumps leading to the end of seafloor spreading in the Mascarene Basin (Fig. 3b) and Chagos splitting off from the Mascarene Plateau (Fig. 3c) were a direct result of a vigorous Réunion plume. This led to short periods of plume-ridge interactions (55-40 Myr вр) and more MORB-like basalt compositions. With time, the Réunion plume probably became less vigorous and ridge-plume distance increased systematically for the past $40 \mathrm{Myr}$. All existing plate reconstructions assume that Chagos belonged to the Indian Plate at $\sim 50$ Myr в (Site 713 , Fig. 1). We show, however, that Chagos was joined to the Mascarenes and that the Réunion plume was beneath the African Plate at this time. Consequently, the Réunion plume remained directly beneath the Indian Plate only for $\sim 10 \mathrm{Myr}$ (65-55 Myr вр). This has implications for modelling plate motions based on hotspot tracks, and we further advise against using volcanics from Site 707 (64.1 Myr вр) when constructing such models, because it was erupted close to the ridge and $\sim 500 \mathrm{~km}$ from the Réunion plume conduit (Supplementary Fig. S6b).

The Seychelles has long been considered as a geological peculiarity, and represents a Precambrian continental fragment left behind after Pangaea break-up. We show here that likewise 

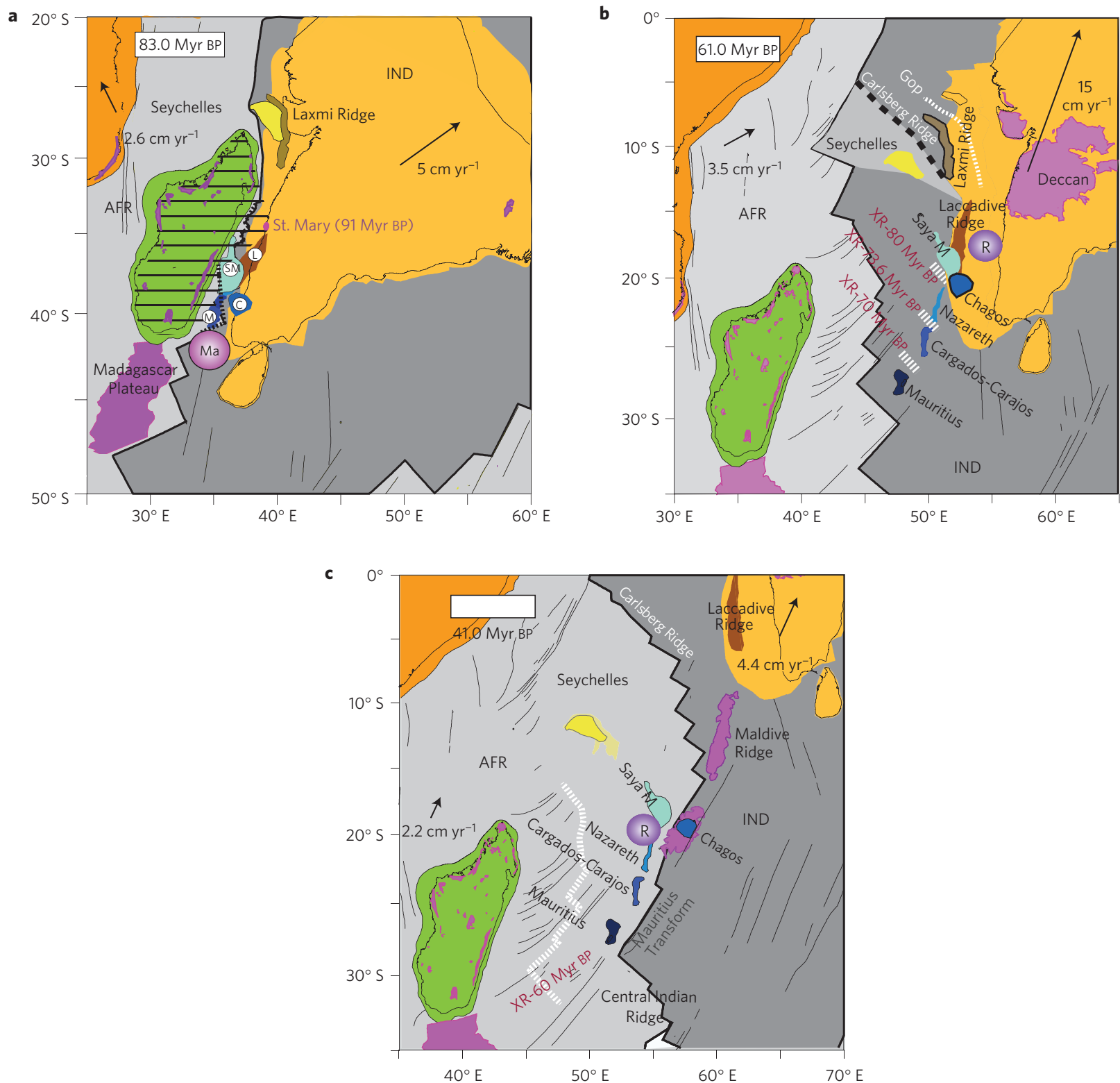

Figure 3 | Late Cretaceous to Eocene plate reconstructions. Mantle reference frame ${ }^{26}$ with surface location for Réunion (R) and Marion (Ma) hotspots. Mean plate speeds calculated for India (IND) and Africa (AFR). a, During the opening of the Mascarene Basin (83.5-70 Myr BP), Mauritius (M) and parts of Mauritia were attached to Madagascar but relocated to the Indian Plate through three southwest-propagating ridge jumps (dashed white extinct ridges, XR). b, At 61 Myr BP, the Réunion plume assisted a northeast-directed ridge jump and the new ridge (Carlsberg) separated Chagos (C) from the Indian Plate. c, At $\sim 41$ Myr BP, a southwest-directed ridge jump returned Chagos to the Indian Plate. SM, Saya de Malha; L, Laccadives.

Mauritius may be underlain by continental lithosphere material and propose that thinned continental crust imaged seismically beneath the Laxmi Ridge ${ }^{16}$ on the conjugate Indian margin, as well as the crust of Mauritia, partly formed through Neoproterozoic arc-related intrusive activity, as in the Seychelles ${ }^{21}$. These proposed continental fragments gradually rifted and were separated from the Indian and African plates, respectively, by a series of Late Cretaceous-Early Cenozoic plate boundary relocations, probably triggered by both the Marion and Réunion plumes. The Indian Ocean could be littered with continental fragments, but the extent of continental crust remains speculative because these fragments have been obscured by hotspot-related volcanism. It is puzzling, but probably coincidental, that absolute plate motions were such that, subsequent to fragmentation, the Réunion hotspot trail followed continental fragments along the Southern Mascarene Plateau for the past $50 \mathrm{Myr}$. We show that the Réunion hotspot trail is close to what is expected from absolute plate motion models, but it is likely that lithospheric heterogeneities, including two major fracture zones, fossil (Cretaceous) ridges and continental lithospheric fragments, combined with plume-ridge interactions, had a subsidiary control on the distribution of surface volcanics. Critical to furthering our tale of lost continents are deep drilling, acquisition of high-quality seismic refraction data, and a rigorous search for zircon xenocrysts, coupled with geochemistry, geochronology and plate reconstructions.

\section{Methods}

Great care was taken to eliminate the risk of contamination when collecting material for $\mathrm{U}-\mathrm{Pb}$ analyses, and two samples from northwest and southeast Mauritius (Supplementary Table S1) were collected from beaches adjacent to eroding columnar basalts. Sampling beach sand eliminates the need for rock crushing and thus the chance for contaminating the sample with zircons from previously processed samples. Beach sands were collected from trenches dug to 
the base of beach foresets, where heavy minerals are concentrated, and sieved and concentrated on location using entirely new equipment. The samples were then sealed until further processing at the University of Oslo. The sand concentrates were passed through $250 \mu \mathrm{m}$ disposable sieves and the finer grained fraction further enriched with a Frantz magnetic separator and heavy liquid (methylene iodide), before the final handpicking in alcohol under a binocular microscope. All of the material used in the separation was either new, or carefully disassembled and cleaned in an ultrasonic bath followed by blasting with a compressed air jet. A general, independent, test for the cleanliness of the procedure in this laboratory is provided periodically when samples of volcanic rocks and mafic dykes subjected to crushing and mineral separation fail to yield even a single zircon grain. The selected zircons were cleaned in acid, and dissolved in Krogh-type dissolution bombs after addition of a mixed ${ }^{205} \mathrm{~Pb} /{ }^{235} \mathrm{U}$ spike. Solutions larger than a few micrograms were passed through anion-exchange columns to isolate $\mathrm{U}$ and $\mathrm{Pb}$. The isotopic measurements were done in a MAT262 mass spectrometer in static mode with multiple Faraday cups or by peak jumping with a secondary electron multiplier, depending on signal strength. Fractionation factors of $0.1 \% \mathrm{amu}^{-1}$ for $\mathrm{Pb}$ and $0.12 \% \mathrm{amu}^{-1}$ for $\mathrm{U}$ were determined by daily measurements of the NBS $982 \mathrm{~Pb}$ and U500 standards. Given the nature of the problem being investigated, it was not deemed necessary to abrade the zircons. Analytical procedures are detailed in ref. 30 .

Satellite-derived gravity anomaly and bathymetry data were used to derive the mantle residual gravity anomaly, and subsequently inverted in the three-dimensional spectral domain to give Moho depth ${ }^{15}$. A thermal gravity anomaly correction was implemented and corrections were made for both sedimentary thickness and crustal volcanic addition due to decompression melting during continental break-up lithosphere thinning and sea-floor spreading. The gravity inversion uses a reference crustal thickness of $36 \mathrm{~km}$, a continental break-up age of $65 \mathrm{Myr}$ вP and a crustal basement density of $2850 \mathrm{~kg} \mathrm{~m}^{-3}$ (see Supplementary Figs S1 and S2).

Absolute plate reconstructions use the global moving hotspot (mantle) reference frame of ref. 26. Relative plate kinematics within the Indian Ocean basin is based on interpretations of marine magnetic anomalies and fracture zones (see Supplementary Information). A principal difference between our plate model and previous Indian Ocean plate reconstructions is that we include extra continental fragments and postulate several ridge jumps that led to important plate boundary relocations. The ages of extinct ridges are inferred from the geometry of plate boundaries at different times, interpretation of magnetic anomalies and high asymmetry of crust production within the southwesternmost spreading corridor of the Mascarene Basin, where much more crust has been accreted to the northeast flank (Supplementary Fig. S4). On the basis of our new plate model we produced a new seafloor age grid for the Indian Ocean (Supplementary Fig. S7).

Received 10 August 2012; accepted 18 January 2013; published online 24 February 2013

\section{References}

1. Richards, M. A., Duncan, R. A. \& Courtillot, V. E. Flood basalts and hotspot tracks: Plume heads and tails. Science 146, 103-107 (1989).

2. Duncan, R. A. in Proc. Ocean Drilling Program Scientific Results Vol. 115 (eds Duncan, R. A., Backman, J. \& Peterson, L. C.) 3-10 (1990).

3. Courtillot, V., Davaille, A., Besse, J. \& Stock, J. Three distinct types of hotspot in the Earth's mantle. Earth Planet. Sci. Lett. 205, 295-308 (2003).

4. National Geophysical Data Center, National Oceanic and Atmospheric Administration, US Department of Commerce, http://www.ngdc.noaa.gov/ mgg/.

5. Burke, K., Steinberger, B., Torsvik, T. H. \& Smethurst, M. A. Plume generation zones at the margins of large low shear velocity provinces on the core-mantle boundary. Earth Planet. Sci. Lett. 265, 49-60 (2008).

6. Torsvik, T. H., Burke, K., Steinberger, B., Webb, S. C. \& Ashwal, L. D. Diamonds sourced by plumes from the core mantle boundary. Nature 466, 352-355 (2010).

7. Vlastelic, I., Lewin, E. \& Staudacher, T. Th/U and other geochemical evidence for the Réunion plume sampling a less differentiated mantle domain. Earth Planet. Sci. Lett. 248, 379-393 (2006).

8. McDougall, I. \& Chamalaun, F. H. Isotopic dating and geomagnetic polarity studies on volcanic rocks from Mauritius, Indian Ocean. Geol. Soc. Am. Bull. 80, 1419-1442 (1969)

9. Moore, J. et al. Evolution of shield-building and rejuvenescent volcanism of Mauritius. J. Volc. Geothermal Res. 207, 47-66 (2011).

10. Paul, D., White, W. M. \& Blichert-Toft, J. Geochemistry of Mauritius and the origin of rejuvenescent volcanism on oceanic island volcanoes. Geochem. Geophys. Geosyst. 6, Q06007 (2005).

11. Paul, D., Kamenetsky, V. S., Hofmann, A. W. \& Stracke, A. Compositional diversity among primitive lavas of Mauritius, Indian Ocean: Implications for mantle sources. J. Volc. Geothermal Res. 164, 76-94 (2007).
12. Grimes, C. B. et al. Trace element chemistry of zircon from oceanic crust: A method for distinguishing detrital zircon provenance. Geology 7, 643-646 (2007).

13. Simonetti, A. \& Neal, C. R. In-situ chemical, U-Pb dating, and Hf isotope investigation of megacrystic zircons, Malaita (Solomon Islands): Evidence for multi-stage alkaline magmatic activity beneath the Ontong Java Plateau. Earth Planet. Sci. Lett. 295, 251-261 (2010).

14. Pilot, J., Werner, C. D., Haubrich, F. \& Baumann, N. Paleozoic and Proterozoic zircons from the Mid-Atlantic Ridge. Nature 393, 676-679 (1998).

15. Greenhalgh, E. E. \& Kusznir, N. J. Evidence for thin oceanic crust on the extinct Aegir Ridge, Norwegian Basin, NE Atlantic derived from satellite gravity inversion. Geophys. Res. Lett. 34, L06305 (2007).

16. Collier, J. S. et al. Factors influencing magmatism during continental breakup: New insights from a wide-angle seismic experiment across the conjugate Seychelles-Indian margins. J. Geophys. Res. 114, B03101 (2009).

17. Chaubey, A. K. et al. Analyses of multichannel seismic reflection, gravity and magnetic data along a regional profile across the central-western continental margin of India. Marine Geol. 182, 303-323 (2001).

18. Henstock, T. J. \& Thompson, P. J. Self-consistent modelling of crustal thickness at Chagos-Laccadive ridge from bathymetry and gravity data. Earth Planet. Sci. Lett. 224, 325-336 (2004).

19. Collins, A. S. \& Windley, B. F. The tectonic evolution of Central and Northern Madagascar and its place in the final assembly of Gondwana. J. Geol. 110, 325-339 (2002).

20. Ashwal, L. D., Demaiffe, D. \& Torsvik, T. H. Petrogenesis of Neoproterozoic granitoids and related rocks from the Seychelles: Evidence for an Andean arc origin. J. Petrol. 43, 45-83 (2002).

21. Collins, A. S., Kinny, P. D. \& Razakamanana, T. Depositional age, provenance and metamorphic age of metasedimentary rocks from southern Madagascar. Gondwana Res. 21, 353-361 (2012).

22. Storey, M. et al. Timing of hot spot-related volcanism and the break-up of Madagascar and India. Science 267, 852-855 (1995).

23. Torsvik, T. H. et al. Late Cretaceous India-Madagascar fit and timing of break-up related magmatism. Terra Nova 12, 220-225 (2000).

24. Collier, J. S. et al. Age of Seychelles-India break-up. Earth Planet. Sci. Lett. 272, 264-277 (2008).

25. Ganerød, M. et al. in The Formation and Evolution of Africa: A Synopsis of 3.8 Gyr of Earth History Vol. 357 (eds Van Hinsbergen, D. J. J., Buiter, S. J. H., Torsvik, T. H., Gaina, C. \& Webb, S. J.) 229-252 (Geol. Soc. Lond. Spec. Publ., 2011).

26. Doubrovine, P. V., Steinberger, B. \& Torsvik, T. H. Absolute plate motions in a reference frame defined by moving hotspots in the Pacific, Atlantic and Indian oceans. J. Geophys. Res. 117, B09101 (2012).

27. Lénat, J-F, Merle, O. \& Lespagnol, L. La réunion: An example of channeled hot spot plume. J. Volc. Geothermal Res. 184, 1-13 (2009).

28. Sleep, N. H. Lateral flow and ponding of starting plume material. J. Geophys. Res. 102, 10001-10012 (1997).

29. White, W. M., Cheatham, M. M. \& Duncan, R. A. in Proc. Ocean Drilling Program Scientific Results Vol. 115 (eds Duncan, R. A., Backman, J. \& Peterson, L. C.) 53-61 (1990).

30. Corfu, F. U-Pb age, setting, and tectonic significance of the anorthositemangerite-charnockite-granite-suite, Lofoten-Vesterålen, Norway. J. Petrol. 45, 1799-1819 (2004).

31. Becker, T. W. \& Boschi, L. A comparison of tomographic and geodynamic mantle models. Geochem. Geophys. Geosyst. 3, 1003 (2002).

\section{Acknowledgements}

We thank E. R. Neuman for discussions, and C. Mac Niocaill for constructive comments. The European Research Council under the European Union's Seventh Framework Programme (FP7/2007-2013)/ERC Advanced Grant Agreement Number 267631 (Beyond Plate Tectonics), the Norwegian Research Council (Topo-4D) and the Centre for Advanced Study are acknowledged for financial support.

\section{Author contributions}

T.H.T., H.A. and B.J. developed the conceptual idea for the study, H.A. and E.H. sampled the Mauritius rocks, F.C. dated the samples, N.K. calculated the crustal thickness map, C.G. and T.H.T developed detailed reconstructions, P.D. and B.S. developed global plate motion frames, and L.D.A. and B.J. handled geochemical aspects. All authors contributed to discussions and writing of the manuscript.

\section{Additional information}

Supplementary information is available in the online version of the paper. Reprints and permissions information is available online at www.nature.com/reprints. Correspondence and requests for materials should be addressed to T.H.T.

\section{Competing financial interests}

The authors declare no competing financial interests. 